\title{
過去了か年におけろ頻骨骨折の臨床的钼察
}

間非羓・赤非元光・术田光徳

\section{Clinicostatistical observation of the maxillofacial fracture during the past 3 years}

\author{
Noriyoshi TAKAI - Motoyoshi AKAI - Mitsunori HoNdA
}

粕

霉

額顔面口腔領战における䫑骨骨折などはわれわれか～ 臨床上遭遇する重要な外隽性疾患の1つである。

近年における交通事情の多梯化汇伴って，交通事故の 複㒕化を生し，また生活様式の变化，スボーツの隆盛， さらに労働による災害などが，影骨骨折の機会を多くし

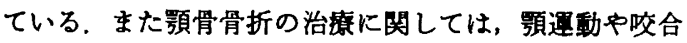
機能回復などの預骨といら特異性のため, 他の骨折治療 と趣が異なっているのて，患者は菌科口腔外科を受誩す る機会が增加しているのである.

今日まて預骨骨折についての報告は数多くみられるが 1 10)，われわれも，過去 3 か年比颃いて大阪労災病院 口腔外科を訪れた䫑骨骨折患者について臨床的䧽察を行 ったのでここに報告する.

症例

\section{1. 対 象}

対象绀昭和51年 6 月より昭和 54 年 5 月までの 3 年間 K, 大阪労災病院口腔外科を受診した频骨骨折患者は59 名で，当科受診患者総数の $1.5 \%$ を占めていた。

2. 年 龄・性 別

性別で恃，男性が50例 (84.7\%) で，女性 9 例 (15.3 \%)に比べ圧倒的に多く，男女比は 5：1 割合であっ た.

年龄層は，5歳から67歳までで，10歳代が18例 (30.5 \%) と最多く，次いで20歳代16例 $(27.1 \%) ， 30$ 歳代

大阪労災病院口腔外科（部長：本田光徳）

Department of Oral Surgery, Osaka Rosai Hospital (Chief: Dr. Mitsunori Honda)

受付日：昭和56年 1 月 25 日

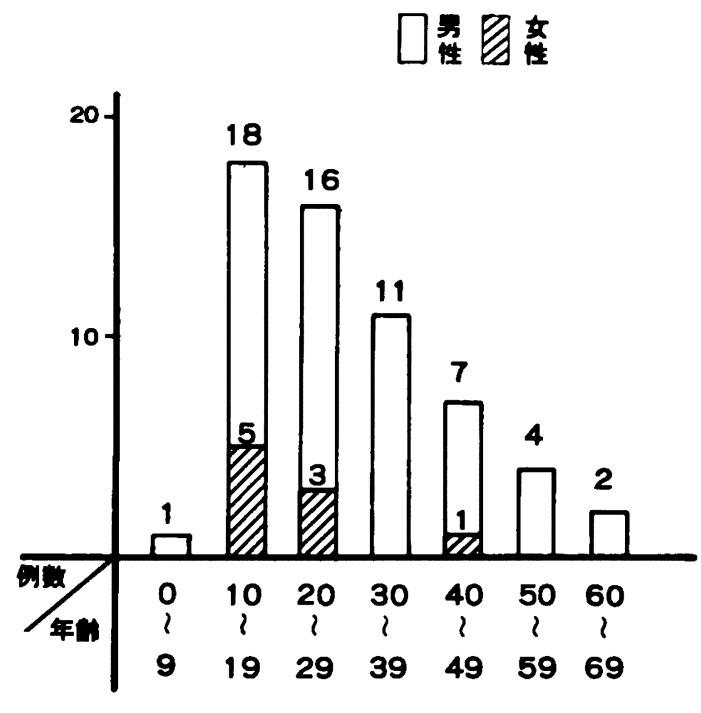

図 1 年龄, 性別

11例（18.6\%）の順であり，10歳から29瓷までの青少年 期か557.6\%を占めていた，女性は10歳代 5 例と 20 歳代 3

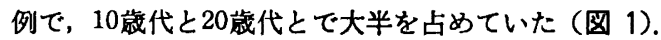

3. 受偪の原因

受稘の原因で最も多いのは，交通事故で，59例中29例 (49.2\%) と，約半数を占めていた．次いで，眨打など の暴力が 8 例 (13.6\%)，スポーツと作業事故がおのお の 6 例 $(10.2 \%)$ ずつであった。 交通事故をさらに詳し く分けてみると，最も多かったのが，自動車運転中で11 例, 自転車運転中が 9 例, 単車運転中が 8 例であった. また残り 1 例は，歩行中の事故であった（表 1).

\section{4. 骨折部位}

上下顎別にみると，下靧骨が46例 $(78.0 \%)$ と大半を 占め, 次いで上顥骨 11 例 $(18.6 \%)$, 上下䫓骨 2 例 (3.4 \%)の順であった（表i2）. 
衰 1 原因则

\begin{tabular}{|c|c|c|c|c|}
\hline & & & 例 数 & $\%$ \\
\hline 交 & 通 事 & 故 & 29 & 49.2 \\
\hline 役 & 打 - 采 & 力 & 8 & 13.6 \\
\hline x & ポ - & $\%$ & 6 & 10.2 \\
\hline 作 & * & 故 & 6 & 10.2 \\
\hline 忶 & & 落 & 5 & 8. 4 \\
\hline 枟 & & 倒 & 5 & 8. 1 \\
\hline & it & & 59 & 100.0 \\
\hline
\end{tabular}

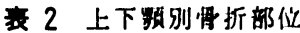

\begin{tabular}{|c|c|c|c|c|c|}
\hline & & & & 㝄 & $\%$ \\
\hline 上 & & & 骨 & 11 & 18. 6 \\
\hline 下 & & & 骨 & 46 & 78. 0 \\
\hline 上 & 下 & 䫅 & 骨 & 2 & 3. 4 \\
\hline \multicolumn{4}{|c|}{ 計 } & 59 & 100.0 \\
\hline
\end{tabular}

表 3 上額骨骨折部位

\begin{tabular}{|c|c|c|c|c|}
\hline & & & 数 & $\%$ \\
\hline 煩 & 骨 & 弓 & 3 & 23. 1 \\
\hline 上 影 & 骨 体 & 部 & 2 & 15.4 \\
\hline 歯 槽 & 突 起 & 部 & 8 & 61.5 \\
\hline \multicolumn{3}{|c|}{ 計 } & 13 & 100.0 \\
\hline
\end{tabular}

表 4 下影骨骨折部位

\begin{tabular}{|c|c|c|c|c|}
\hline & & & 数 & $\%$ \\
\hline 関 & 節 & 部 & 23 & 31.8 \\
\hline$\pi$ & $r \quad \pi 1$ & 部 & 13 & 18.1 \\
\hline 角 & & 部 & 13 & 18. 1 \\
\hline 小 & 臼歯 & 部 & 7 & 9.7 \\
\hline 大 & 臼 菌 & 部 & 3 & 4. 2 \\
\hline 犬 & 㐘 & 部 & 2 & 2.8 \\
\hline 筩 & 突 起 & 部 & 1 & 1.4 \\
\hline 切 & 痕 & 部 & 1 & 1.4 \\
\hline 上 & 行 枝 & 部 & 1 & 1.4 \\
\hline 歯 & 槽 突 起 & 部 & 8 & 11.1 \\
\hline & 計 & & 72 & 100.0 \\
\hline
\end{tabular}

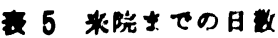

\begin{tabular}{|c|c|c|c|c|}
\hline & & & 低 数 & $\%$ \\
\hline \multirow[t]{3}{*}{ 受 } & this & 岸 日 & 7 & 11.9 \\
\hline & & 2 日 & 12 & 20.3 \\
\hline & & $3 \mathrm{H}$ & 10 & 16.9 \\
\hline 1 & 造 & 以内 & 1.3 & 22.1 \\
\hline 2 & in & 以内 & 10 & 16.9 \\
\hline 3 & in & 以 & 2 & 3.4 \\
\hline .1 & 造 & 以 & 4 & 6.8 \\
\hline 1 & 遛 & 以 上 & 1 & 1.7 \\
\hline & & & 59 & 100.0 \\
\hline
\end{tabular}

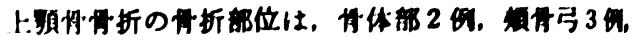

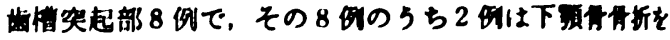
合併していた

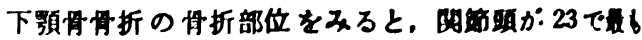
多く，次いでオトガイ部，角部かおのおの 13，小比

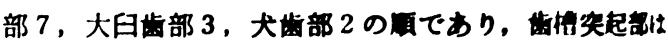
8 であった（表 3，4）.

\section{5. 来院むでの日数むよひ来院释路}

来院までの日数では，1迥间以内が42名 (71.2\%), 2 週間以内が10名 (16.9\%) で大半を占めていた， 竞

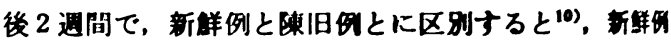
は52例 (88.1\%)，陳旧例は7例 (11.9\%)であった (衰 5).

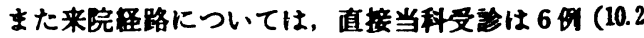
\%)にすぎず，大半は救急病院の䂏介によるるのであっ た.

\section{6. 治湴について}

治㫫は，骨体部骨折と齿模骨骨折に分けて考え，また

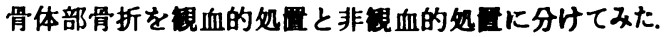

上頻骨では，骨体部骨折 5 例の5ち钼血的処置が 例，非観血的処直が 1 例であった。

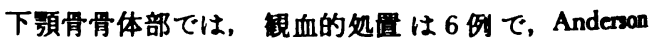
あるいは H-H 式 Pin を用いたのか３作，A-O Plate を用いたのが 2 例，骨粘合を用いたのが 2 例であった (表 6).

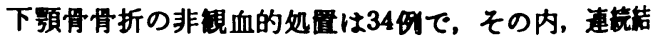
紫法すしくは線副子を用いての預間固定法が29网と大半 で，次いで線副子のみを用いた例が 3 例，線副子と Chin cap を併用した例が 2 例であった（表 7).

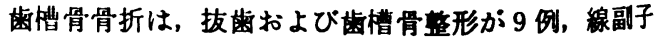
または連続結禁法を用いた整復固定が 7 例であった。

7. 固定期間

副子の除去または患者の機能回復をるって骨折の治索 とみなすと，観察期間は表 8 に示すこととくであるが，上 
表 6 下顎骨骨折・微血的処倩

\begin{tabular}{|c|c|}
\hline Pin & 2 \\
\hline Pin十嗃梡桔禁 & 1 \\
\hline Plate & 1 \\
\hline Plate+骨䋊合 & 1 \\
\hline 骨綎合十䝷間固定 & 1 \\
\hline 計 & 6 \\
\hline
\end{tabular}

表 7 下䫑骨骨折・非覾血的処圈

\begin{tabular}{|c|c|}
\hline 線副子＋穎間固定 & 24 \\
\hline 連繶桔禁＋影間固定 & 4 \\
\hline 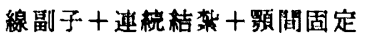 & 1 \\
\hline 線副子 & 3 \\
\hline 線副子+Chin cap & 2 \\
\hline 計 & 34 \\
\hline
\end{tabular}

表 8 矮察期間

\begin{tabular}{|c|c|c|c|c|c|c|}
\hline & & & & 上額 & 下疑 & 上下影 \\
\hline 4 & 週 & 未 & 満 & 3 & 1 & \\
\hline 8 & 週 & \multicolumn{2}{|l|}{ " } & 4 & 20 & 2 \\
\hline 12 & 週 & \multicolumn{2}{|c|}{ "I } & 3 & 6 & \\
\hline 12 & 週 & 以 & 上 & 2 & 16 & \\
\hline
\end{tabular}

不明 3 例

靧骨の 4 週未満の 3 例は歯槽骨骨折で, 下顎骨は 8 週未 満が21例と多く，12週以上が16例であった。

不明の 3 例の $5 ち 2$ 例は他病院より骨折治療の依頼に よるため予後不明，他の 1 例は無断退院による予後不明 であった。

\section{総括および考察}

最近数年間の社会情势の急激な变化，ならびに，各種 交通機関の発達とともに額顔面領域の外傷も增加してい る。また，外傷患者の中には開口障害や咬合異常を主訴 として来院し，精査の結果，たまたま㴿骨骨折と判明す る場合もある，また，口腔の特殊性を熟知せずに治療に あたり，後遺症としての咬合の異常や開口障害, 顔貌の 変形を起こす場合る少なくない.このような意味で,わ れわれ歯科医は骨折患者の治療にあたり重要な役割をお。 びていると思うのである。

性别に関しては男女比は 5:1 と他の報告 ${ }^{1210)}$ 同様に男 性が多数を占め，現在の社会的な活動を考えてみると当 然である。
年粭では，10敞代に樶む频発しているところが，他の

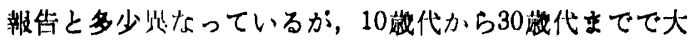

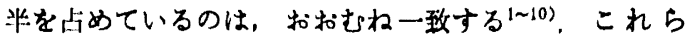

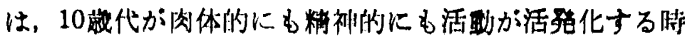

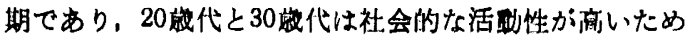
に受伤の機会が多くなると思われる，女性が10放代と20 殿代に大多数みられるのは，それ以降家涏での仕徉 事するので受徏の機会が少なくなったと考えられる。

原因については，多くの報告は交通掉故が多いとして いるが，野問1は交通将故に上るものが43.5\%を占め，

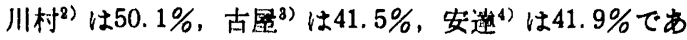
ったとしている，われわれの報任で交通事故か49.2\% と取も多く，その中でも自転缉と样車によるものが17例 (58.6\%) と多数を占めていることは，最近の交通機関 の発達の一過程としての二輪車の䇣用が 1 つの原因にな っていると考えられるのである.

顥骨骨折を，上下額別にみてみると，一般に下影䯚骨 折が王倒的に多く，われわれる下顥骨骨折か $78.0 \%$ と大 多数を占めていた，下䫑骨骨折が頻発することについて は，林 ${ }^{12)}$ は，上頻骨は頭蓋骨に保護され受傷の機会が少 ないのに対し，下䫟骨は顔面頭蓋の底を作り，解剖学的 位㯰と形態とにより受賃の機会が多いとしている。また

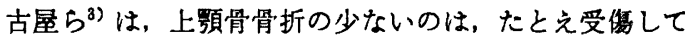
も頭部の外傷を併発していることが多いことから，その 治㞠が優先されるためと考えている.

次に下䪽骨について骨体部骨折部位別にみると，関節 頭, オトガイ部，角部の順に多くみられた。これは川村 ら²) の報告とほぼ一致するむ，他の報告1,3〜10) とは異な る結果が得られた，われわれの得た結果は，岡"1)の報告 する下買骨の形態的弱点部位と一致すると思われた.

来院までの日数では，1 週間以内が42例 $(71.2 \%)$ を 占め，受侮から初診までの日数は，処㥜および予後にお いて重要である，われわれの経験で，2 週間以上を経て 来院した患者の大部分は，他部位の外伤の処置が優先さ れ，やむを得ず来院までの日数が連れたためと考えられ る。また来院経路は当科直接受診は 6 例 $(10.2 \%)$ にすき ず,他の大半は救急病院の紹介によるものであった.そこ で古屋ら ${ }^{3)}$ ，久野ら ${ }^{9)}$ が述べているように，一般医と雨 科医ならびに口腔外科医とが密接な連絡をとり，可及的 早期に治療を開始することが望ましいと思らのである。

治㞠内容は，下顎骨骨体部骨折では非観血的処置を行 ったものか $85 \%$ と大部分を占めた，方法は連続結禁法も しくは，線副子と筫間固定法をおもに用いた，観血的処 置はピン固定法, プレートや骨縫合であった。このよう な観血的処置は，前に述へた非観血的処置では整復固定 が不十分な場合に行ったが，すなわち，残存齿牙が少な い場合や，また陳旧性骨折で整復か観血的手術に頼らね ば不可能な場合であった。

上顎骨骨折の治療は，上顎洞根本手術と領間固定を併 


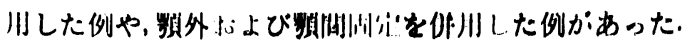

\section{むす び}

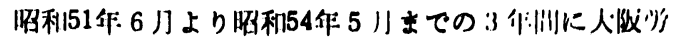

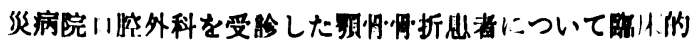
覞察を行った。

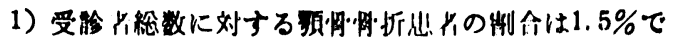
あった。

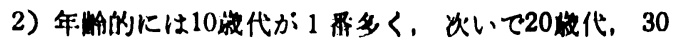
放代に多くみられた。 な将男女此は5:1であった。

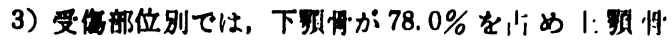
$18.6 \%$ ，上下顆用· $3.4 \%$ と絖いていた。

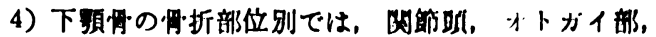
角部が多かった。

5）原因別では交通拃故か $49.2 \%$ と約半数を占めてい た.

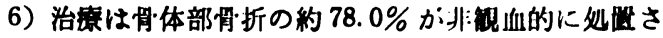
れた。

7）米院までの経路は值接当科を受跈したものは 10.2 \%にすぎなかった。

（本論交の要旨は昭和54年10月27日，第 5 回日位口胵外 科学会近成地方会にて発表した。)

\section{引用文 献}

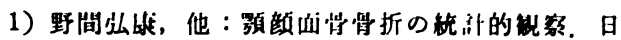

11外就 18: 4501972.

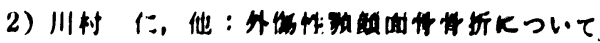
11口外赫23: 8091977.

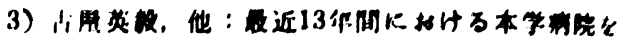

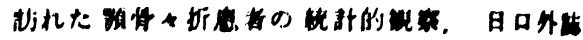
16: 181970.

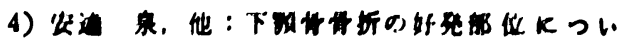
$\tau$. 20: 1311980.

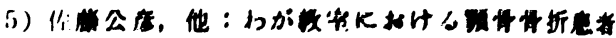

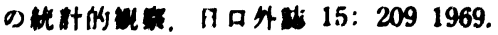

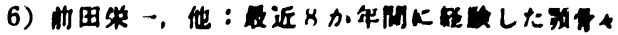

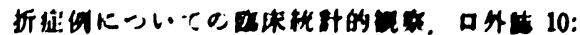
2741964.

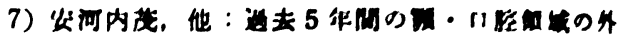

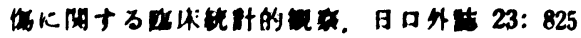
1977.

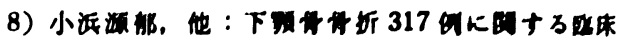

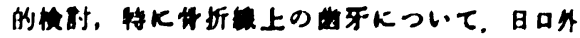
15: 2371977.

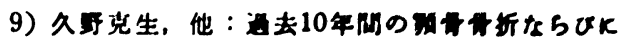

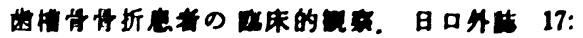
5131971.

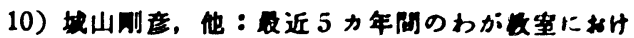

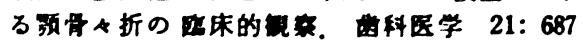
1959.

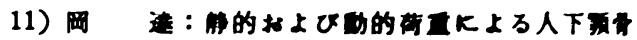
麦面の歪Kついて。只科行 6:74 1959.

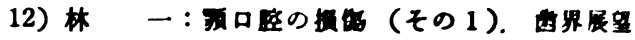
21: 171963 . 